\title{
Monoclonal antibodies to Treponema pallidum: recognition of a major polypeptide antigen
}

\author{
ROBERT W THORNBURG, JANICE MORRISON-PLUMMER, AND \\ JOEL B BASEMAN \\ From the Department of Microbiology, The University of Texas Health Science Center, San Antonio, \\ Texas, USA
}

SUMMARY Hybridomas secreting monoclonal antibodies that reacted with a 45000 dalton surface polypeptide and major immunogen of $T$ pallidum were produced. This polypeptide was also found in $T$ pertenue but not in $T$ hyodysenteriae or $T$ phagedenis biotype Reiter.

\section{Introduction}

Although recent reports have described biochemical and immunological properties of Treponema pallidum, ${ }^{1-25}$ the causative agent of venereal syphilis and non-venereal endemic syphilis or bejel, much remains unknown about the biology of the disease. The humoral immune response appears to play an important part in the pathophysiology of syphilitic infections, and specific surface treponemal proteins have been identified as major immunogens. ${ }^{34}$ 6-8

To further characterise treponemal antigens, we used hybridoma technology to produce antibodies to $T$ pallidum. We describe monoclonal antibodies that bind to a 45000 dalton surface protein of the treponeme.

\section{Materials and methods}

\section{ORGANISMS}

$T$ pallidum (Nichols strain) and $T$ pertenue (Gautier strain) were provided by the Center for Disease Control, Atlanta, Georgia and were maintained by routine passage in rabbits. Adult New Zealand white rabbits (3-4 $\mathrm{kg}$ ), obtained locally, were inoculated intratesticularly with $50 \times 10^{6}$ treponemes and treated with $6 \mathrm{mg} / \mathrm{kg}$ cortisone acetate (Merck Sharpe and Dohm, West Point, Pennsylvania, USA) on days 3-7 after infection. Peak orchitis occurred at days 10-14 for $T$ pallidum and days 24-30 for $T$ pertenue. Stock solutions were prepared from infected rabbit testes as described previously. ${ }^{2} T$ phagedenis biotype Reiter was grown in Spirolate broth supplemented

\footnotetext{
Address for reprints: Dr J B Baseman, Department of Microbiology, University of Texas Health Science Center, 7703 Floyd Curl Drive, San Antonio, Texas 78284, USA
}

Accepted for publication 3 March 1984 with $0.6 \%$ glucose and $10 \%$ heat inactivated rabbit serum. ${ }^{26} T$ hyodysenteriae was a gift of Dr Hank Harris, University of Iowa, Iowa, and was grown in anaerobically reduced media. ${ }^{27}$ ( $T$ hyodysenteriae cultures produce large quantities of hydrogen gas. Care was therefore taken to ventilate these closed cultures to prevent the build up of explosive pressures.)

\section{RADIOLABELLING OF ORGANISMS}

$T$ pallidum harvested from rabbit testes at peak orchitis were concentrated by centrifugation $(12000 \times g$ for 20 minutes) in sterile tubes. Treponemes were resuspended in $2 \mathrm{ml}$ of minimal essential medium without methionine (Gibco, Grand Island, New York, USA) but containing $10 \%$ dialysed fetal calf serum and 0.5-1 mCi ${ }^{35} \mathrm{~S}$-methionine and were incubated aerobically overnight. Then the treponemes were washed three times in $0.05 \mathrm{~mol} / 1$ TRIS and $0.2 \mathrm{~mol} / \mathrm{l}$ sodium chloride $(\mathrm{pH} 8 \cdot 0)$, pelleted, and frozen at $-20^{\circ} \mathrm{C}$ until used.

\section{IMMUNISATION}

To generate activated mouse spleen cells, freshly extracted and purified $T$ pallidum $\left(300 \times 10^{6}\right.$ $T$ pallidum in $0.5 \mathrm{ml}$ saline) were emulsified $1 / 1$ (vol/vol) in Freund complete adjuvant, and injected. intramuscularly $(0.1 \mathrm{ml})$, subcutaneously $(0.1 \mathrm{ml})$, or intraperitoneally $(0.3 \mathrm{ml})$ into BALB/c female mice (3-6 weeks old). On days 7 and 21 the mice were similarly boosted with treponemes emulsified in Freund incomplete adjuvant.

\section{CELL HYBRIDISATION}

Monoclonal antibodies were produced by modification of the procedure of $\mathrm{Oi}$ and Herzenberg. ${ }^{28}$ Spleen cells from immunised mice and SP2/0-Ag14 
BALB/c myeloma cells were washed separately in Dulbecco's modified Eagle's medium (DME) free of serum (MA Bioproducts, Walkersville, Maryland, USA) and then combined in a ratio of $7: 1$. The basic method of cell fusion was as described by us earlier. ${ }^{29}$ A volume of $50 \mu$ of the fused cell preparation was aliquoted into each well of 96 well microtitre tissue culture plates (Bellco, Vineland, New Jersey, USA) containing $0.1 \times 10^{6}$ normal BALB/c spleen feeder cells in $50 \mu \mathrm{l}$ of DME-HAT (containing $0.2 \mathrm{mmol} / 1$ hypoxanthine, $0.7 \mathrm{mmol} / \mathrm{l}$ aminopterin, and 32 $\mathrm{mmol} / 1$ thymidine $)^{30}$ plus glycine. One day after fusion, $100 \mu \mathrm{l}$ of DME-HAT plus glycine were added to each well. Plates were incubated at $37^{\circ} \mathrm{C}$ in $7 \%$ carbon dioxide for seven to 10 days before being screened by an enzyme linked immunosorbent assay (ELISA). Selected hybrid cells were cloned by limiting dilution in 96 well microtitre tissue culture plates containing $0.1 \times 10^{6} \mathrm{BALB} / \mathrm{c}$ spleen feeder cells/well. Clones were expanded for analysis by ELISA.

ATTACHMENT OF ANTIGEN TO POLYVINYLCHLORIDE MICROTITRE PLATES Individual pellets of treponemes ( $T$ pallidum, $T$ pertenue, $T$ hyodysenteriae, and $T$ phagedenis biotype Reiter) were resuspended in coating buffer ${ }^{31}$ and sonicated using six 15 second bursts with 45 second intermittent incubations on ice (Sonifier Cell Disruptor Model W140D, Heat Systems-Ultrasonics, Plainview, New York, USA). The protein concentration of each treponemal preparation was measured by the Lowry method. ${ }^{32}$ Aliquots of $100 \mu \mathrm{l}$ of $1.0 \mathrm{mg} / \mathrm{ml}$ treponemal protein in coating buffer were distributed into each well of Immunlon 2 strips (Dynatech, Alexandria, Virginia, USA) and incubated overnight at $4^{\circ} \mathrm{C}$. The plates were then filled with $1 \%$ bovine serum albumin in phosphate buffered saline (BSA/PBS) and incubated for two hours at $37^{\circ} \mathrm{C}$.

Purified $T$ pallidum proteins were isolated from polyacrylamide gels ${ }^{33}$ and diluted to $1 \mathrm{mg} / \mathrm{ml}$ in coating buffer, ${ }^{31}$ aliquoted ( $50 \mathrm{ng} /$ well) into Immulon 2 strips, and incubated overnight at $4^{\circ} \mathrm{C}$. If not used immediately, plates were washed once with PBS, filled with $1 \%$ BSA/PBS, and stored at $-20^{\circ} \mathrm{C}$.

\section{ENZYME LINKED IMMUNOSORBENT ASSAY (ELISA)}

A modified ELISA as previously reported by us ${ }^{29} 33$ was used to detect antibodies to sonicated and purified treponemal proteins.

SERUM SAMPLES

Normal and immune mouse serum was collected by retro-orbital bleeding of BALB/c mice before and after inoculating them with $T$ pallidum. Normal and syphilitic rabbit serum was obtained before or 47 days after infection with $T$ pallidum. Normal and syphilitic human serum was provided by Dr J Jorgenson at Medical Center Hospital, San Antonio, Texas. All serum samples were stored at $-20^{\circ} \mathrm{C}$ before use.

\section{SODIUM DODECYL SULPHATE (SDS)}

POLYACRYLAMIDE GEL ELECTROPHORESIS

Treponemal proteins were electrophoresed on $7 \cdot 5 \%$ polyacrylamide slab gels in the discontinuous TRISglycine system described by Laemmli. ${ }^{34}$ After one dimensional electrophoresis, gels were fixed in methanol, acetic acid, and water in a ratio of 45:45:10 and either processed for fluorography with preparations labelled with ${ }^{35} \mathrm{~S}$-methionine ${ }^{35}$ or dried immediately and exposed to $x$ ray film for samples labelled with radioactive iodine $\left({ }^{125} \mathrm{I}\right)$.

\section{IODINATION OF PROTEIN A}

Using the lactoperoxidase labelling method of Marchalonis et $a l^{36} 100 \mathrm{mg}$ protein A was labelled with $1 \mathrm{mCi}$ radioactive iodine for $\mathbf{3 0}$ minutes to give ${ }^{125}$ I-protein A. After radiolabelling, iodinated protein $\mathbf{A}$ was purified from unreactive radioactive iodine and denatured protein $\mathbf{A}$ by passage over a $1 \mathrm{ml}$ column of IgG-Sepharose, which was prepared by coupling IgG purified by protein $A$ chromatography to Sepharose 4B activated by cyanogen bromide. ${ }^{37}$ Fractions of $1 \mathrm{ml}$ of the PBS eluate were collected until the column background was reduced to less than 5000 counts per minute (cpm) $/ 10 \mu \mathrm{l}$ aliquot. The bound ${ }^{125} \mathrm{I}$-protein $\mathrm{A}$ was eluted with $\mathrm{pH} 2 \cdot 8$ glycine hydrochloride and separated from the low molecular weight glycine by subsequent passage over a $0.8 \times 25 \mathrm{~cm}$ column of Biogel P-10 in PBS.

\section{WESTERN BLOTS}

Aliquots (20-40 $\mu \mathrm{g}$ protein) of unlabelled treponemes were solubilised in $0.063 \mathrm{~mol} / 1$ TRIS containing $2 \%$ sodium dodecyl sulphate (SDS), 2\% $\beta$-mercaptoethanol, and $10 \%$ glycerol, and were electrophoresed on a $7 \cdot 5 \%$ polyacrylamide slab gel. The proteins were then electrophoretically transferred for 16 hours at $380 \mathrm{~mA}$ to nitrocellulose paper (BioRad, Richmond, California, USA) using the technique of Towbin et al. ${ }^{38}$ One lane was stained with amido black to show whether both high and low molecular weight proteins were successfully transferred to the nitrocellulose sheets. Non-specific protein binding sites were blocked by incubation in 3\% BSA/PBS for six hours. The nitrocellulose strips were then incubated overnight with constant rocking in a 1/50 dilution of antiserum in 3\% BSA/PBS or with monoclonal ascites purified antibody. The strips were rinsed in either PBS plus $0.01 \%$ SDS or PBS 
alone and incubated with 3\% BSA/PBS containing ${ }^{125}$ I-protein $\mathrm{A}$. The strips were finally rinsed as before, dried, and exposed to $x$ ray film (Kodak XR5) with an enhancing screen. ${ }^{39}$

\section{PURIFICATION OF MONOCLONAL ANTIBODIES ON PROTEIN A SEPHAROSE}

Monoclonal antibodies were generated as ascites in pristine primed BALB/c mice. ${ }^{28}$ The ascites fluid was diluted to $20 \%$ in $0.01 \mathrm{~mol} / 1$ phosphate buffer $(\mathrm{pH}$ $7 \cdot 2$ ) and passed over a $1.5 \times 8 \mathrm{~cm}$ protein A-Sepharose column. The column was eluted with $0.01 \mathrm{~mol} / 1$ phosphate buffer $(\mathrm{pH} 7 \cdot 2)$ until the background absorbance $\left(\mathrm{A}_{280}\right)$ was less than 0.02 , followed by elution with $0 \cdot 1 \mathrm{~mol} / 1$ glycine $(\mathrm{pH} 2 \cdot 8)$. The fractions containing protein as determined by $\mathrm{A}_{280}$ were pooled and dialysed in a two step process, first against 1000 volumes of $\mathrm{pH} 5.5$ citrate phosphate buffer $(0.05 \mathrm{~mol} / \mathrm{l}$ citric acid, $0.05 \mathrm{~mol} / \mathrm{l}$ disodium hydrogen phosphate, and $0.145 \mathrm{~mol} / \mathrm{l}$ sodium chloride; $\mathrm{pH}$ adjusted with $6 \mathrm{~mol} / \mathrm{l}$ sodium hydroxide) and finally against 1000 volumes of PBS. The protein concentrations were measured, and the monoclonal $\mathrm{IgG}$ was diluted to $1 \mathrm{~g} / 1$ with PBS.

\section{Results}

Hybridoma culture supernatants were screened for reactivity to whole $T$ pallidum organisms fixed in ethanol. Of about 1200 hybridomas tested, 54 clones bound selectively to $T$ pallidum. To analyse the specificity of the binding sites of these monoclonal antibodies, culture supernatants were screened by ELISA using gel eluted $T$ pallidum proteins. ${ }^{33}$ Treponemal proteins corresponding to specific regions of SDS-polyacrylamide gels were purified and pooled as follows: high molecular weight (HMW) (proteins over 100000 daltons); P5,6

TABLE I Reactivity of normal and immune mouse serum and monoclonal antibodies $11 F_{2}, 13 F_{3}$, and $23 C_{9}$ to $T$ pallidum proteins eluted from sodium dodecyl sulphate polyacrylamide gels

\begin{tabular}{lllll}
\hline & & \multicolumn{2}{l}{ Mean $(S D)^{*}$ reactivity to T pallidum proteins } \\
\cline { 3 - 5 } & Dilution & $H M W(O D)$ & $P 5,6(O D)$ & $P 1,2,3,4(O D)$ \\
\hline NMS & $1: 50$ & $0.049(0.006)$ & $0.059(0.002)$ & $0.061(0.004)$ \\
IMS & $1: 50$ & $0.072(0.015)$ & $0.375(0.024)$ & $0.355(0.115)$ \\
& $1: 100$ & $0.033(0.004)$ & $0.357(0.021)$ & $0.237(0.097)$ \\
$11 F_{2}$ & $1: 100$ & $0.005(0.034)$ & $0.138(0.047)$ & $0.034(0.019)$ \\
$13 F_{3}$ & $1: 100$ & $0.003(0.005)$ & $0.260(0.075)$ & $0.001(0.004)$ \\
$23 C_{9}$ & $1: 100$ & $0.002(0.003)$ & $0.244(0.033)$ & $0.030(0.024)$ \\
\hline
\end{tabular}

* Mean (SD) of quadruplicate samples. PBS control $\leqslant 0.017$. $\mathrm{HMW}=$ heavy molecular weight (>100 000 daltons); P1 (89 500 daltons), P2 (29 500 daltons), P3 (25 500 daltons), P4 (20 000 daltons), P5 (59 000 daltons), P6 (42 500 daltons).

For meanings of other abbreviations see table II.
(59 000 and 42 500); and P1,2,3,4 (89 500, 29500 , 25500,20000 daltons). These protein designations (P1-P6) are consistent with previous reports. ${ }^{346-8}$ As shown in table I, immune mouse serum (IMS) obtained just before killing for the hybridoma fusion reacted predominantly with protein pools P1-4 and P5,6; there was low reactivity towards the high molecular weight antigen group. Normal mouse serum (NMS) showed poor reactivity to all antigen groups examined.

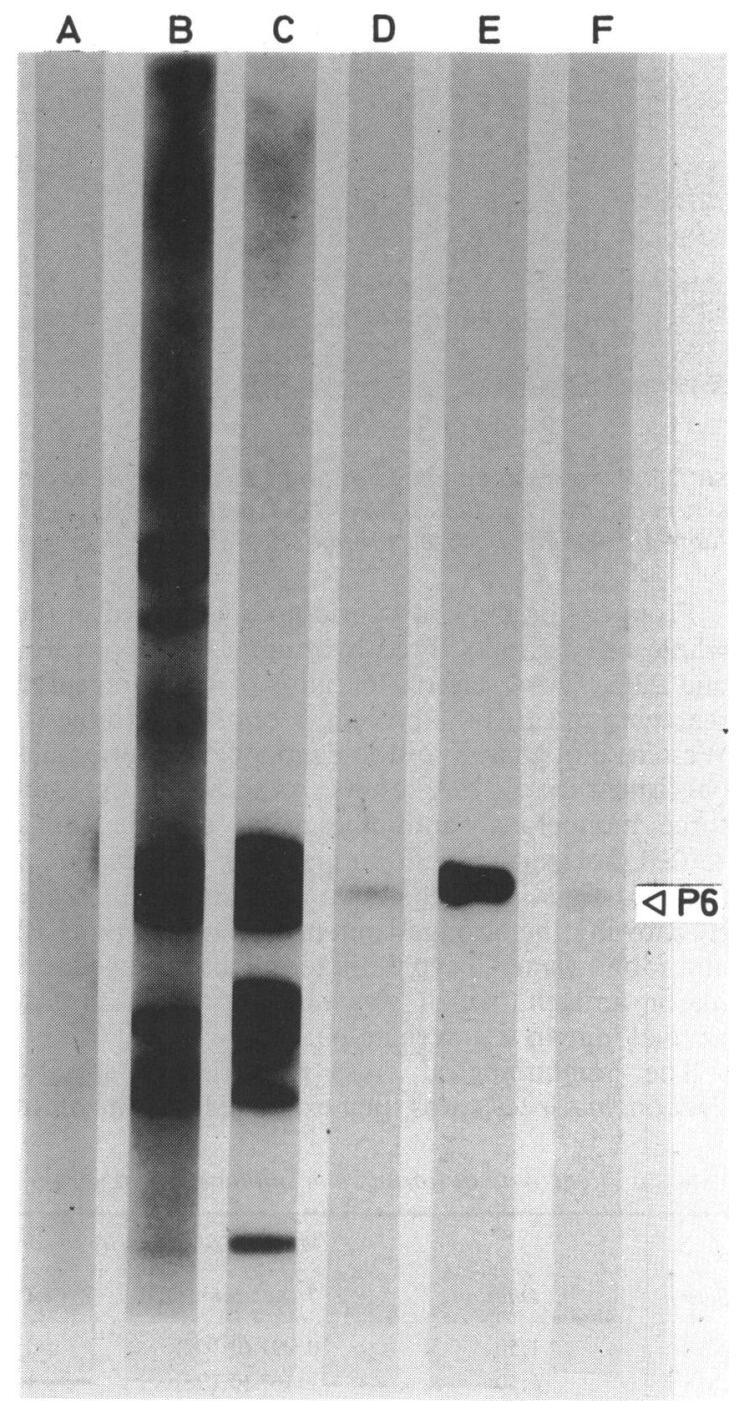

FIG 1 Western blot analysis of: normal human serum (lane A); syphilitic human serum (lane B); syphilitic rabbit serum (lane $C$ ); monoclonal antibody $11 F_{2}$ (lane $D)$; monoclonal antibody $13 F_{3}$ (lane $E$ ); and monoclonal antibody $23 C_{9}$ (lane $F$ ) against $T$ pallidum antigens. 


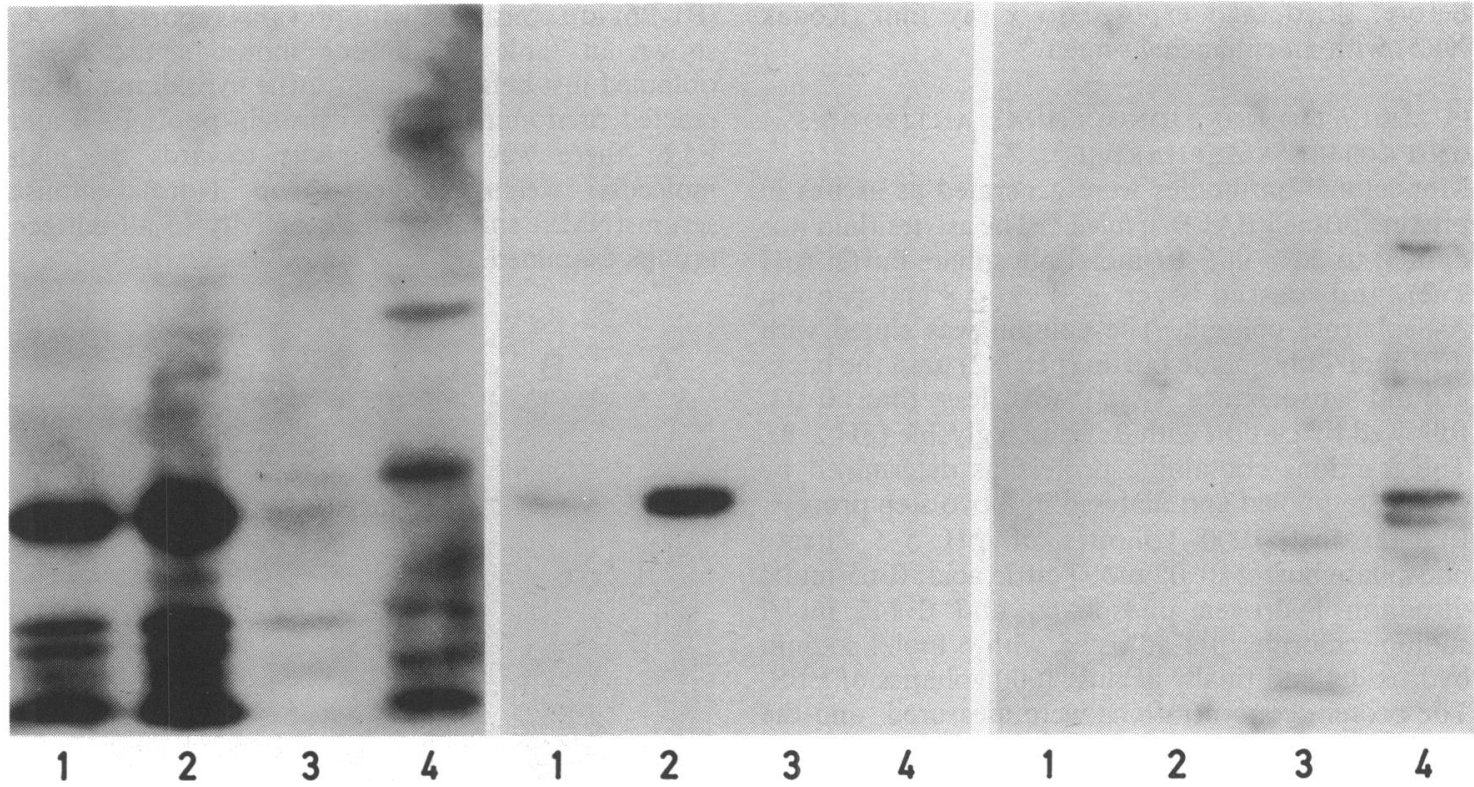

FIG 2 Western blot analysis of (a) syphilitic rabbit serum, (b) monoclonal antibody $13 F_{3}$, and (c) normal rabbit serum against: $T$ pallidum (lane 1$) ; T$ pertenue (lane 2); $T$ hyodysenteriae (lane 3); and $T$ phagedenis biotype Reiter (lane 4) solubilised and electrophoresed on a $7 \cdot 5 \%$ polyacrylamide slab gel.

From the original 54 hybridomas identified in the whole cell ELISA, three hybridomes, $\left(11 \mathrm{~F}_{2}, 13 \mathrm{~F}_{3}\right.$, and $23 \mathrm{C}_{9}$ ) were selected because of their increased reactivity towards the protein pool of P5,6 (table I). Western blot analysis of these monoclonal antibodies confirmed the ELISA results. As shown in fig 1, all three monoclonal antibodies were specific for a 45000 molecular weight antigen (P6) of $T$ pallidum (lanes D-F), with monoclonal hybridoma $13 \mathrm{~F}_{3}$ (lane E) showing the strongest intensity. Human (lane B) and rabbit (lane $C$ ) syphilitic serum also showed this major antigen, which was not present in pooled normal human serum (lane A).

The immunological cross reactivity of specific Treponema species was then examined. As shown in table II, immune mouse serum was strongly cross reactive with $T$ pallidum and $T$ pertenue antigens and, to a lesser extent, with $T$ hyodysenteriae and $T$ phagedenis indicating shared or cross reactive antigens. Normal mouse serum showed low reactivity to $T$ pallidum and $T$ pertenue, and somewhat increased reactivity to $T$ hyodysenteriae and $T$ phagedenis. To further examine the cross reactivity of these species, Western blot analysis was performed using both normal and syphilitic rabbit serum and monoclonal antibody $13 \mathrm{~F}_{3}$. ELISA typing of antibody $13 \mathrm{~F}_{3}$ showed the isotype to be IgG2a, $x$ light chain. Only one single heavy and light chain was obtained following SDS-polyacrylamide gel electrophoresis of the antibody. As shown in fig 2, syphilitic

TABLE II Reactivity of normal and immune mouse serum to various treponemal species

\begin{tabular}{|c|c|c|c|c|c|}
\hline \multirow[b]{2}{*}{ Serum } & \multirow[b]{2}{*}{ Dilution } & \multicolumn{4}{|c|}{ Mean $(S D) *$ reactivity to sonicated treponemal antigens $\dagger$} \\
\hline & & $T$ pallidum $(O D)$ & $T$ pertenue $(O D)$ & $T$ hyodysenteriae (OD) & $T$ phagedenis (OD) \\
\hline NMS & $1: 50$ & $0.091(0 \cdot 002)$ & $0.058(0 \cdot 008)$ & $0 \cdot 157(0 \cdot 019)$ & $0.259(0.027)$ \\
\hline IMS & $\begin{array}{l}1: 50 \\
1: 100 \\
1: 500\end{array}$ & $\begin{array}{l}1 \cdot 167(0.035) \\
1 \cdot 179(0.072) \\
1 \cdot 825(0.086)\end{array}$ & $\begin{array}{l}1 \cdot 121(0.110) \\
0.967(0.018) \\
0.763(0.064)\end{array}$ & $\begin{array}{l}0.507(0.146) \\
0.314(0.026) \\
0.059(0.012)\end{array}$ & $\begin{array}{l}0.916(0.070) \\
0.761(0.031) \\
0.450(0.004)\end{array}$ \\
\hline
\end{tabular}

* Mean (SD) of quadruplicate samples. PBS control $\leqslant 0 \cdot 017$.

tTreponemes were prepared and sonicated as described in Materials and methods. Treponemal proteins were coated on to microtitre strips at a concentration of $1 \mu \mathrm{g}$ protein per well.

$\mathrm{OD}=$ optical density at $405 \mathrm{~nm}$; NMS = normal mouse serum; IMS = immune mouse serum. 
rabbit serum (a) showed cross reactive antigens among all four treponemal species. Normal rabbit serum (c) did not react with $T$ pallidum (lane 1) or $T$ pertenue (lane 2) but low level reaction occurred with $T$ hyodysenteriae (lane 3 ) and $T$ phagedenis biotype Reiter (lane 4). Monoclonal antibody $13 \mathrm{~F}_{3}(\mathrm{~b})$ was highly selective for the 45000 dalton protein antigen (P6) found in $T$ pallidum ${ }^{3}$ and $T$ pertenue. ${ }^{9}$ No cross reactive protein was shown by $13 \mathrm{~F}_{3}$ in $T$ hyodysenteriae or $T$ phagedenis.

\section{Discussion}

A group of 54 monoclonal antibodies reactive with $T$ pallidum were produced. Three hybridoma clones were selected for further study because of their unique specificity for a 45000 dalton molecular weight polypeptide, P6. Antibodies to this protein have been shown to appear early (day 10) in rabbits experimentally infected with $T$ pallidum. ${ }^{15}$ This protein also exhibits high immunogenicity in infected rabbits and man. ${ }^{346}$

Monoclonal antibody $13 \mathrm{~F}_{3}$ was purified by protein A-Sepharose chromatography and used to examine cross reactivity among four species of treponemes (fig 2). In contrast to polyclonal antiserum raised against $T$ pallidum, which shows strong reactivity with all four species of treponemes, monoclonal $13 \mathrm{~F}_{3}$ reacted only with $T$ pallidum and $T$ pertenue. These data further emphasise the close relation between these two treponemes, ${ }^{90}$ and reinforce the biological differences between the treponemes pathogenic and non-pathogenic to man.

The immune response to syphilis is extremely complex and includes both humoral and cellmediated immunity. Monoclonal antibody probes offer the opportunity to evaluate better the role of specific treponemal antigens in the pathophysiology of the disease. ${ }^{94142}$ The availability of monoclonal probes also permits further biochemical and immunochemical dissection of important antigens and enables the development of rational diagnostic reagents and vaccines.

We thank Mary Devadoss for her excellent secretarial help and Diane Jones and Andrew Bird for their technical help. This work was supported by Public Health Service Grant AI-19566 from the National Institute of Allergy and Infectious Diseases and by Cistron Technology Incorporated.

\section{References}

1. Hayes NS, Muse KE, Collier AM, Baseman JB. Parasitism by virulent Treponema pallidum of host cell surfaces. Infect Immun 1977; 17:174-86.

2. Alderete JF, Baseman JB. Surface-associated host proteins on virulent Treponema pallidum. Infect Immun 1979; 26: 1048-56.

3. Alderete JF, Baseman JB. Surface characterization of virulent Treponema pallidum. Infect Immun 1980;30:814-23.
4. Baseman JB, Hayes EC. Molecular characterization of receptor binding proteins and immunogens of virulent Treponema pallidum. J Exp Med 1980;151:573-86.

5. Fitzgerald TJ. Pathogenesis and immunology of Treponema pallidum. Annu Rev Microbiol 1981;35:29-54,

6. Baseman JB, Alderete JF. The parasitic strategies of Treponema pallidum. In: Schell RF, Musher DM, eds. Pathogenesis and immunology of treponemal infection. New York: Marcel Dekker, 1983;229-39.

7. Peterson, KM, Baseman JB, Alderete JF. Treponema pallidum receptor binding proteins interact with fibronectin. J Exp Med 1983; 157: 1958-70.

8. Baseman JB, Alderete JF. The biology of Treponema pallidum and syphilis. Clinical Microbiology Newsletter 1983;5:157-9.

9. Thornburg RW, Baseman JB. Comparison of major protein antigens and protein profiles of Treponema pallidum and Treponema pertenue. Infect Immun 1983; 42:623-7.

10. Friedmann PS, Turk JL. A spectrum of lymphocyte responsiveness in human syphilis. Clin Exp Immunol 1975; 21:59-64.

11. Weiser RS, Erickson D, Perine PL, Pearsall NN. Immunity to syphilis: passive transfer in rabbits using serial doses of immune serum. Infect Immun 1976; 13:1402-7.

12. Bishop NH, Miller JN. Humoral immunity in experimental syphilis. I. The demonstration of resistance conferred by passive immunization. J Immunol 1976; 117: 191-6.

13. Bishop NH, Miller JN. Humoral immunity in experimental syphilis. II. The relationship of neutralizing factors in immune serum to acquired resistance. J Immunol 1976; 117:197-207.

14. Pavia CS, Folds JD, Baseman JB. Cell-mediated immunity during syphilis. British Journal of Venereal Diseases 1977;53: 144-50.

15. Alderete JF, Baseman JB. Analysis of serum IgG against Treponema pallidum protein antigens in experimentally infected rabbits. British Journal of Venereal Diseases 1981;57:302-8.

16. Strandberg-Pedersen N, Axelsen NH, Petersen CS. Antigenic analysis of $T$ pallidum: cross reaction between individual antigens of $T$ pallidum and $T$ Reiter. Scand $J$ Immunol 1981; 13: $143-50$.

17. Sell S, Gambosa D, Baker-Zander SA, Lukehart SA, Miller JN. Host response to Treponema pallidum in intradermally infected rabbits. Evidence for persistence of infection at local and distant sites. $J$ Invest Dermatol 1980; 75:470-5.

18. Lukehart SA, Baker-Zander SA, Gubish ER. Identification of Treponema pallidum antigens: comparison with a non-pathogenic treponeme. J Immunol 1982; 129:833-8.

19. Baughn RE, Adams CB, Musher DM. Circulating immune complexes in experimental syphilis: identification of treponemal antigens and specific antibodies to treponemal antigens in isolated complexes. Infect Immun 1983; 42:585-93.

20. Baughn RE. Immunoregulatory effects in experimental syphilis. In: Schell RF, Musher DM, eds. Pathogenesis and immunology of treponemal infection. New York: Marcel Dekker, 1983;271-95.

21. Bishop NH, Miller JN. Humoral immune mechanisms in acquired syphilis. In: Schell RF, Musher DM, eds. Pathogenesis and immunology of treponemal infection. New York: Marcel Dekker, 1983:241-69.

22. Folds JD. Cell-mediated immunity. In: Schell RF, Musher DM, eds. Pathogenesis and immunology of treponemal infection. New York: Marcel Dekker, 1983;315-30.

23. Lukehart SA. Macrophages and host resistance. In: Schell RF, Musher DM, eds. Pathogenesis and immunology of treponemal infection. New York: Marcel Dekker, 1983;349-64.

24. Schell RF, Chan JK, Lefrock JL. In: Schell RF, Musher DM, eds. Pathogenesis and immunology of treponemal infection. New York: Marcel Dekker, 1983;331-48.

25. Sell S. Histopathology and immunopathology of experimental syphilis. In: Schell RF, Musher DM, eds. Pathogenesis and immunology of treponemal infection. New York: Marcel Dekker, 1983;297-313.

26. Christiansen AH. The Reiter strain of Treponema pallidum: origin, cultivation, and use in immunization of rabbits. Acta Pathol Microbiol Scand 1963;57:81-6.

27. Kinyon JM, Harris DL. Growth of Treponema hyodysenteriae in a liquid medium. Vet Rec 1974;95:219-20.

28. Oi VT, Herzenberg LA. Immunoglobulin-producing hybrid cell lines. In: Mishell BB, Shiigi SM, eds. Selected methods in cellular immunology. San Francisco: WH Freeman, 1980; $351-72$. 
29. Morrison-Plummer J, Jones DH, Baseman JB. An ELISA to detect monoclonal antibodies specific for lipid determinants of Mycoplasma pneumoniae. JImmunol Methods 1983;64: 165-78.

30. Kennett RH. In: Kennett RH, McKearn TJ, Bechtol KB, eds Monoclonal antibodies hybridomas: a new dimension in biological analyses. New York: Plenum Press, 1980;365-7.

31. Voller A, Bidwell D, Bartlett A. Microplate enzyme immunoassays for the immunodiagnosis of virus infections. In: Rose NR, Friedman H, eds. Manual of clinical immunology. Washington DC: American Society for Microbiology, 1976; 506-12.

32. Lowry OH, Rosebrough NJ, Farr AL, Randall RJ. Protein measurement with the folin phenol reagent. $J$ Biol Chem 1951; 193:265-75.

33. Morrison-Plummer J, Alderete JF, Baseman JB. Enzymelinked immunosorbent assay for the detection of serum antibody to outer membrane proteins of Treponema pallidum. British Journal of Venereal Diseases 1983;59:75-9.

34. Laemmli UK. Cleavage of structural proteins during the assembly of the head of bacteriophage T4. Nature 1970; 227:680-5.

35. Bonner WM, Laskey RA. A film detection method for tritiumlabeled proteins and nucleic acids in polyacrylamide gels. Eur $J$ Biochem 1974;46:83-8.
36. Marchalonis JJ, Cone RE, Santer V. Enzymatic iodination: a probe for accessible surface proteins of normal and neoplastic lymphocytes. Biochem $J$ 1971; 124:921-7.

37. March SC, Parikh I, Cuatrecasas P. A simplified method for cyanogen bromide activation of agarose for affinity chromatography. Anal Biochem 1974;60: 149-52.

38. Towbin H, Staehelin T, Gordon J. Electrophoretic transfer of proteins from polyacrylamide gels to nitrocellulose sheets: procedure and some applications. Proc Natl Acad Sci USA 1979; 76:4350-4.

39. Swainstrom R, Shank PR. X-ray intensifying screens greatly enhance the detection by autoradiography of radioactive isotopes 32P and 125I. Anal Biochem 1978;86: 18492

40. Miao RM, Fieldsteel AH. Genetic relationship between Treponema pallidum and Treponema pertenue, two noncultivable human pathogens. $J$ Bacteriol $1980 ; 141: 427-9$.

41. Robertson SM, Kettman JR, Miller JN, Norgard MV. Murine monoclonal antibodies specific for virulent Treponema pallidum (Nichols). Infect Immun 1982; 36: 1076-85.

42. Saunders JM, Folds JD. Development of monclonal antibodies that recognize Treponema pallidum. Infect Immun $1983 ; 41: 844-7$ 